\title{
The Union in court: Allister and others' Application for Judicial Review [2021] NIQB 64
}

\author{
Anurag Deb* \\ Queen's University Belfast \\ Correspondence email: adebo1@qub.ac.uk
}

\section{INTRODUCTION}

\begin{abstract}
A $\mathrm{n}$ hour before the end of 2020, the Brexit implementation period ended in the United Kingdom (UK). In much of the European Union (EU), 2021 had already begun. From that time, the Protocol on Ireland/Northern Ireland (the Protocol) to the Withdrawal Agreement between the UK and $\mathrm{EU}^{1}$ has governed much of everyday life in Northern Ireland, but not Great Britain. A mere seven months on, the Protocol has had a tumultuous journey, with London and Brussels exchanging sharp words over its implementation, while nervously watching empty supermarket shelves and rising sectarian tensions in Northern Ireland.

On 30 June 2021, the Northern Ireland High Court handed down judgment in Allister and others' application for judicial review ${ }^{2}$ in which the Protocol and its attendant legislation were challenged on multiple grounds. In a dense, comprehensive and keenly awaited judgment, $\mathrm{Mr}$ Justice Colton dismissed all five grounds of an extraordinary challenge. The unenviable difficulty of delving into the roots of the famously uncodified UK constitution was compounded by the febrile politics surrounding the Protocol itself. Colton J's efforts are, therefore, considerable and commendable.

In what follows, I examine the facts of the case before turning to the judgment in three main sections: first, its implications for
\end{abstract}

\footnotetext{
* I am grateful to Dr Conor McCormick and to the anonymous peer reviewer for their helpful comments on an earlier draft of this piece. All views and any errors, however, are my own.

1 Protocol on Ireland/Northern Ireland Agreement on the withdrawal of the United Kingdom of Great Britain and Northern Ireland from the European Union and European Atomic Energy Community [2019] OJ C 384 I/01.

2 [2021] NIQB 64, Colton J. I do not cover the related case of Peeples's application for judicial review for reasons of economy on what is an already lengthy piece. The salient point in Colton J's judgment in Peeples was that the Protocol does not breach the Northern Ireland Act 1998 or the Good Friday Agreement 1998 and that the latter has not been incorporated generally into domestic law: [318]-[319].
} 
'constitutional' statutes; second, its implications for devolution in Northern Ireland; and, third, miscellaneous matters.

\section{THE PROTOCOL: A GAME OF THREES}

A detailed examination of the Protocol is both unnecessary and outside the scope of this piece. ${ }^{3}$ Indeed, its provisions are as complex as they are long. Instead, this article suffices to focus on six main points, in two sets of three.

The first set of three points relates to the content and agreement of the Protocol itself: first, that the Protocol was intended to 'address the unique circumstances on the island of Ireland'; ${ }^{4}$ second, that 'Northern Ireland has in effect remained in the EU single market for goods' as well as in the UK's single market, 5 so that goods originating in Northern Ireland may be traded tariff and barrier-free in both the EU and Great Britain; ${ }^{6}$ and, finally, that the Protocol was itself agreed (and ratified) after a series of intensely political failures in the UK Parliament. ${ }^{7}$

The second set of three points concerns the manner in which the Protocol was incorporated into UK domestic law, through three key pieces of legislation: ${ }^{8}$ the European Union (Withdrawal) Act 2018 (EUWA) which prescribed the requirements for ratification of a withdrawal agreement; the European Union (Withdrawal Agreement) Act 2020 (the 2020 Act) which incorporated the Withdrawal Agreement and Protocol; and the Protocol on Ireland/Northern Ireland (Democratic Consent Process) (EU Exit) Regulations 2020 (the Consent Regulations) which provided for the Northern Ireland Assembly to express itself as to whether aspects of the Protocol would continue to apply, in periodic votes to be held for this purpose.

As Colton J observed, the effect of the Protocol's operation is for some EU law to continue to apply in Northern Ireland but not in Great Britain, necessitating 'new checks and administrative burdens on businesses in G[reat] B[ritain] providing goods to Northern Ireland'9

However, for detail see Sylvia de Mars, EU Law in the UK (Oxford University Press 2020).

$4 \quad$ Protocol (n 1 above) C 384 I/92.

$5 \quad$ Allister (n 2 above) [16].

6 Protocol (n 1 above) art 5, C 384 I/94.

$7 \quad$ Allister (n 2 above) [8]-[10].

8 Colton J mentions the Trade and Cooperation Agreement as a 'key further instrument in the Withdrawal architecture' (see Allister (n 2 above) [29]) but this was the last mention of that Agreement in the judgment and that Agreement is, in any event, irrelevant in my analysis. 
which have 'proven extremely controversial in Northern Ireland and ... are opposed by all the unionist political parties'.10

The Protocol and its incorporation were challenged on five grounds: first, that they violated the Acts of Union 1800; second, that they breached constitutional guarantees that Northern Ireland's political status would not change except by referendum; third, that they sidestepped the consociational heart of Northern Ireland's constitutional framework; fourth, that they breached the European Convention on Human Rights; and, finally, that they breached EU law. ${ }^{11}$ I deal with each ground in turn.

\section{THE UNION CHALLENGE}

The Acts of Union 1800 were simultaneous statutes passed by the Parliament of Great Britain ${ }^{12}$ and the Parliament of Ireland 13 in order to unite the two islands into one country. Among the many provisions of this new union was article VI, which is worth setting out in full:

That it be the Sixth Article of Union, that his Majesty's subjects of Great Britain and Ireland shall, from and after the first day of January, one thousand eight hundred and one, be entitled to the same privileges and be on the same footing, as to encouragements and bounties on the like articles, being the growth, produce or manufacture of either country respectively, and generally in respect of trade and navigation in all ports and places in the United Kingdom and its dependencies; and that in all treaties made by his Majesty, his heirs and successors, with any foreign power, his Majesty's subjects of Ireland shall have the same privileges, and be on the same footing as his Majesty's subjects of Great Britain.

The Protocol, however, provides for customs duties to be charged for goods entering Northern Ireland from another part of the UK or elsewhere outside of the EU, if those goods are at risk of subsequently being moved into the EU.14 Thus, although goods originating in Northern Ireland may freely be moved elsewhere in the UK, ${ }^{15}$ some goods which originate outside Northern Ireland, even if they originate elsewhere in the UK, will be charged customs duties when entering Northern Ireland. Thus, even without assessing evidence of disruption in trade between Northern Ireland and Great Britain, ${ }^{16}$ Colton $J$ was

\footnotetext{
10 Ibid [19].

11 Ibid [44].

12 Union with Ireland Act 1800.

13 Act of Union (Ireland) 1800.

14 Protocol (n 1 above) art 5.1, C 384 I/94.

15 See in particular Protocol (n 1 above) art 6.1, C 384 I/96.

16 Allister (n 2 above) [61].
} 
able to point to the design of the Protocol itself as cutting across the 'same footing' command in article VI. ${ }^{17}$

The challenge under this ground proceeded along two lines: first, that the Acts of Union prevented the UK from making an agreement which breached the 'same footing' command under article VI;18 and, second, that the provisions of the Acts of Union were supreme over the provisions of the Protocol (thus retaining the 'same footing' command over the provisions in the Protocol). ${ }^{19}$

In aid of the first submission, counsel for the applicants, former Northern Ireland Attorney General John Larkin QC, referred to international law, specifically article 46 of the Vienna Convention, ${ }^{20}$ which prohibits a state from invalidating its consent to a treaty on the basis of that consent having been provided in violation of some rule of domestic law (of that state) 'unless that violation was manifest and concerned a rule of [that state's] internal law of fundamental importance'. Essentially, the argument was that the UK Government could not have consented to a treaty in breach of article VI, and thus the consent provided was invalid. Labelling the point 'an excursion',21 Colton $\mathrm{J}$ dispatched with it very briefly, observing that the Withdrawal Agreement (and thus the Protocol) had been signed on authorisation from the Prime Minister, and that treaty-making was in any event a matter of 'high politics' ill-suited to scrutiny by the courts. ${ }^{22}$ Moreover, the Withdrawal Agreement had been ratified in accordance with the provisions of the EUWA, ${ }^{23}$ meaning that parliamentary will had been followed to the letter. As the UK constitution does not contain a doctrine more fundamental than the sovereignty of the Crown in Parliament, the Protocol remains unimpeachable on this point.

The second submission is where the judgment reaches its densest point and its richest potential. To begin, article VI is couched in sweeping language when it comes to 'same footing' between Great Britain and Northern Ireland. Equally sweeping is the reach of section 7A of the EUWA (as inserted in that Act by the 2020 Act), which provides for the availability in domestic law of all 'rights, powers, liabilities, obligations and restrictions, from time to time created or arising by or under' the Withdrawal Agreement, without such matters needing any

17 Ibid [62].

18 Ibid [63].

19 Ibid [80].

201155 UNTS 331 (entry into force: 27 January 1980).

21 Allister (n 2 above) [66].

22 Ibid [67].

23 S 13; Allister (n 2 above) [69]. 
further enactment. ${ }^{24}$ Section 7A(3) goes even further, requiring every enactment to be read and given effect to subject to the rights, powers, liabilities, obligations, restrictions, remedies and procedures arising under the Withdrawal Agreement and having effect in domestic law.

With the court thus caught between Scylla and Charybdis, the parties provided diametrically opposed solutions. The applicants argued that the Acts of Union were constitutional in character and therefore should be supreme over the EUWA or the 2020 Act. 25 The respondents argued that there was no proper hierarchy of statutes, so that the court should simply prefer the newer statute to the older one. ${ }^{26}$

Colton $J$ was unable to agree with the applicants, 'in light of the analysis of the reviewability of the [treaty-making] power and the manner in which Parliament has legislated for the Withdrawal Agreement including the Protocol', stating 'to adopt Mr Larkin's argument would be to in effect to render section 7A inoperative'. ${ }^{27}$ The judge also disagreed with the respondents, in that existing case law points to there being a hierarchy of statutes, ${ }^{28}$ constitutional statutes having been defined by Lord Justice Laws in Thoburn. ${ }^{29}$ However, while Laws LJ had defined the term in the context of a conflict between a constitutional statute and an ordinary statute, the task for Colton $J$ was to resolve a conflict between two constitutional statutes.

Ultimately, Colton J preferred the newer statute (with the Protocol) over the older Acts of Union for two main reasons: first, that in the centuries since the Acts of Union had come into force, there had been much profound change enacted to their provisions, observing rather understatedly, 'Much constitutional water has passed under the bridge since the enactment of the Act of Union.' 30 Thus, even a constitutional statute could be subject to implied repeal. I deal with these changes in more detail below. Secondly, the judge observed that article VI was 'open textured' in its language, in contrast to the specificity of the provisions under section 7A of the EUWA. ${ }^{31}$ In the circumstances, centuries-old general language must yield to very recent specific text.

Although Colton $\mathrm{J}$ did not explicitly hold that article VI (or any part thereof) had been repealed, impliedly or otherwise, Colin Murray has described the judge's reasoning as 'a classical assertion of implied

24 EUWA 2018, s 7A(1)(a), in language almost identical to the repealed s 2(1) of the European Communities Act 1972.

25 Allister (n 2 above) [80].

26 Ibid [83].

27 Ibid [81].

28 Ibid [83]-[87].

29 Thoburn $v$ Sunderland City Council [2003] QB 151 [62].

30 Allister (n 2 above) [96]-[108].

31 Ibid [110]. 
repeal', while finding it 'difficult to square with some of the discussion in the Supreme Court's HS2 decision'.32 It is important to explore this tension, not least because Allister is perhaps the first time any court in the UK has had to resolve a conflict between two constitutional statutes.

At the outset, it is important to note that although the court's guiding light was the sovereignty of Parliament, what the court was in fact concerned with was the question of how to give effect to the enactments of a sovereign Parliament. The distinction is important both on a conceptual as well as a practical level. Traditionally understood, parliamentary sovereignty encapsulates the unrestricted ability of the Crown in Parliament to enact law, ${ }^{33}$ but, once enacted, the work of giving effect to that law rests with the courts. Of course, this general statement yields to specific exceptions, where the manner in which a statute is given effect is contained in the statute itself. A famous example of this is section 3(1) of the Human Rights Act 1998, and a second (and more relevant) example is section 7A(3) of the EUWA (as discussed earlier). So, the key question for the courts when faced with two conflicting statutes is how they are to be given effect. Generally, the more recent statute is favoured over the less recent where the conflict between them cannot be interpretively resolved, for the fundamental reason that a sovereign Parliament cannot bind its equally sovereign successors. 34

However, the above norms of statutory construction start to unravel when faced with constitutional statutes. Although Laws LJ defined such a statute as 'one which (a) conditions the legal relationship between citizen and state in some general, overarching manner, or (b) enlarges or diminishes the scope of what we would now regard as fundamental constitutional rights',35 it is clear that such statutes may also condition horizontal relationships between governmental or constitutional elements in just as much an overarching manner as vertical relationships between citizen and state. The Acts of Union, for example, while providing for the treatment of citizens in the new Union, also explicitly provide for the manner of the Crown's succession ${ }^{36}$ and the maintenance of pre-existing judicial structures and jurisdictional heterogeneities, ${ }^{37}$ so that, following union, Ireland did not become subsumed into a single jurisdiction with England in

32 Colin Murray, 'Vichy France and vassalage: hyperbole versus the Northern Ireland Protocol' (UKCLA, 1 July 2021).

33 See Albert Venn Dicey, Introduction to the Study of the Law of the Constitution (Macmillan 1899) 38.

34 Ibid 62-64.

35 Thoburn (n 29 above) [62].

36 Act of Union (Ireland) 1800, art II.

37 Ibid art VIII. 
the same way as Wales had been nearly a quarter of a millennium earlier. ${ }^{38}$ Even article VI conditions both vertical relationships (in terms of the entitlement of citizens in the new union) and horizontal relationships (treaty-making powers, for example). Similarly, the EUWA (as amended by the 2020 Act), in addition to conditioning the new relationship between citizen and state in respect of pre-existing rights and obligations under EU law, ${ }^{39}$ distributes new powers between central and devolved authorities in connection with Brexit. 40 Thus, when a court is faced with a conflict between constitutional statutes, the manner in which such a conflict is resolved has the potential for farreaching consequences beyond the domain of citizen-state relations.

It is in this context that a straightforward application of the doctrine of implied repeal is somewhat problematic. In $R$ (HS2 and others) $v$ Transport Secretary, a joint judgment from Lord Neuberger PSC and Lord Mance JSC, which had the Supreme Court's unanimous approval, contained a short statement which, as Murray points out, conflicts with an assertion of implied repeal of a constitutional statute:

It is, putting the point at its lowest, certainly arguable (and it is for United Kingdom law and courts to determine) that there may be fundamental principles, whether contained in other constitutional instruments or recognised at common law, of which Parliament when it enacted the European Communities Act 1972 did not either contemplate or authorise the abrogation. ${ }^{41}$

Although stated in the context of whether EU law was supreme over constitutional principles in UK domestic law, 42 the Supreme Court acknowledged that constitutional statutes may operate in a manner which restrains subsequent constitutional statutes from having unrestricted effect. This, of course, conflicts with the idea that a more recent sovereign Parliament may impliedly repeal legislation enacted by a previous sovereign Parliament. Discussing the implications of this judgment, Mark Elliott argued that HS2 heralded a new approach to interpreting constitutional statutes: that conflicts between such statutes should be resolved 'by reference to their respective fundamentality'; in other words, whichever of the conflicting constitutional statutes is the more (or most) fundamental within the UK constitution is

38 Laws in Wales Acts 1535-1542.

39 EUWA, s 4.

40 EUWA, ss 10-12 and sched 2.

41 [2014] UKSC 3, [2014] WLR 324, [207], and Murray (n 32 above).

42 Ibid 382D, [206]. 
preferable in effect to those other statutes with which it conflicts. ${ }^{43}$ Obviously, the determination of relative fundamentality in light of the lack of a supreme constitutional text necessitates a degree of judicial scrutiny of non-formal criteria: 'functional, institutional or normative' criteria within the statutes to be scrutinised.44 There is no obvious or straightforward way to determine the relative fundamentality of norms, some of which are creatures of the common law. 45 The reason for this is because, in the UK, constitutional norms have never been neatly listed into a hierarchy of fundamentality. 46 When a court has to consider such a hierarchy, it has to do so in a multi layered context: the statutes which are in conflict, the factual matrix relevant to the conflict, any other constitutional norms which may be relevant (or may be impacted by the court's decision) and so on.

What this discussion illustrates is the difficulty Colton $\mathrm{J}$ faced when having to determine which of the two constitutional statutes before him should be given effect. In the judge's reasoning, two main points supported the EUWA over article VI: first, the significant constitutional developments which had been the subject of legislation since the Acts of Union, so that, among other things, the Ireland of today is unrecognisable through the lens of 1801 and Brexit is unrecognisable through the lens of 1998 (the making of the Good Friday Agreement and the return of devolution to Northern Ireland). Second, the difference in language between the two statutes: the generality of the Acts of Union in contrast with the specificity of the EUWA. Although such reasoning reinforces the sovereignty of Parliament, it is also problematic: the lack of any reference to $H S 2$ by Colton $J$ raises a question as to whether the judgment was brought to the court's attention, 47 in circumstances where implied repeal is not a straightforward matter.

Returning to my earlier discussion of the nature of constitutional statutes, it is plain to see that both the Acts of Union and the EUWA condition vertical and horizontal relationships. In such circumstances,

43 Mark Elliott, 'Constitutional legislation, European Union law and the nature of the United Kingdom's contemporary constitution' (2014) 10(3) European Constitutional Law Review 379, 388.

44 Ibid 386.

45 Cf the 'principle of legality', outlined by Lord Steyn in $R v$ Home Secretary ex $p$ Pierson [1998] AC 539 (HL), 587C.

46 Similar difficulties were highlighted by Mark Elliott in an earlier article about constitutional statutes, 'Embracing "constitutional" legislation: towards fundamental law?’ (2003) 54(1) Northern Ireland Legal Quarterly 25, 39, fn 56, and also in 'Parliamentary sovereignty and the new constitutional order: legislative freedom, political reality and convention' (2002) 22(3) Legal Studies 340.

47 Not having seen the parties' submissions, I do not know whether HS2 featured in them. 
the implied repeal of one statute by the other, as a matter of legal effect, risks jeopardising the certainty and predictability of pre-existing relationships and their attendant rights and obligations. The context here is crucial because, while legal uncertainty in the private sphere may be a mere unavoidable annoyance, in the constitutional sphere, the consequences can be severe. The UK Government has already been criticised for limiting parliamentary scrutiny of the Withdrawal Agreement (which eventually led to the 2020 Act and the incorporation of the Protocol), 48 with the UK Government's chief Brexit negotiator Lord Frost testifying that the impact to businesses trading under the Protocol had a 'bigger chilling effect' than previously thought 49 and the Prime Minister having provided 'assurances' in Parliament that the EUWA did not impliedly repeal article VI50 (which had no impact on Colton J's judgment). ${ }^{51}$ The result of the Government's apparent 'enact now and don't ask questions later' approach to the most constitutionally significant change in generations negatively impacts on the certainty needed to keep constitutional relationships functional. Of course, the level of scrutiny afforded to a Bill by Parliament before its enactment is (from an orthodox viewpoint) 52 immaterial to the enforcement of that enactment by the judiciary. Constitutionally, however, legislative scrutiny matters when courts are asked to give effect to language that has far-reaching implications for constitutional functioning by dramatically changing a pre-existing constitutional landscape. An internal customs and regulatory border bisecting a single customs territory, with one side of that border having to apply a foreign customs and regulatory code, is at least dramatic enough to warrant sufficient scrutiny before enactment. Scrutiny is also crucial here because the risk of implied repeal jeopardising constitutional certainty is prospective: the implied repeal of a past constitutional statute by a relatively rushed present one sets the precedent for another rushed constitutional change by implied repeal in the future.

It is therefore constitutionally (if not strictly legally) insufficient to point to the enactment of a statute as a fait accompli when it is left to the courts to make sense not only of the language of one statute, but the way that language interacts with previous statutes which occupy the same field. In this way, the distinctions between law and politics

48 Hannah White, 'The government's timetable is designed to frustrate Brexit scrutiny' (Institute for Government, 22 October 2019).

49 European Scrutiny Committee, Oral Evidence: The UK's New Relationship with the EU (17 May 2021) Q 57.

50 HC Deb 16 June 2021, vol 697, col 276.

51 Allister (n 2 above) [117].

52 See $R$ (SC and others) $v$ Work and Pensions Secretary [2021] UKSC 26, per Lord Reed PSC [167]-[173]. 
in the UK constitution collapse as the courts face questions of law with considerable political significance. Elliott had argued that one possible way to resolve a conflict between two constitutional statutes was 'on a normal implied-repeal basis, the constitutional status of the two statutes cancelling out the significance of their being constitutional statutes in the first place'.53 As the above discussion shows, implied repeal is not a straightforward resolution to such a conflict, in part because the constitutional implications of certain statutes (beyond the strictly legal field) are wider than the judicial arena. This is not to suggest that the courts should be embroiled in political questions, but only to highlight that such matters cannot be entirely ignored.

Colton J's second point (specificity of language) is also somewhat problematic. The judge states:

... Article VI is open textured. This is to be contrasted with the specificity of section 7A which expressly refers to the terms of the Withdrawal Agreement. The Withdrawal Agreement is a detailed specific and complex agreement making provision for the withdrawal of the United Kingdom from the European Union, the repeal of the 1972 EC Act and the details for the implementation of the Agreement. These specific details are in marked contrast to the general provisions of Article VI and give further weight to the proposition that in recognising the principle of the supremacy of primary legislation and the importance of 'constitutional' statutes that section 7A should be given effect. 54

While section 7A of the EUWA is concerned with the general implementation of the provisions of the Withdrawal Agreement, there are additional powers conferred by the EUWA which are worth highlighting. Sections $8-8 \mathrm{C}$ of the EUWA deal with powers in connection with the UK's withdrawal, empowering ministers to make regulations to deal with deficiencies arising from the withdrawal itself (section 8), the implementation period (section 8A), 'certain other separation issues' (section 8B) and the Protocol (section 8C). Section $8 \mathrm{C}$ has no sunset clause (unlike sections 8 and 8A), highlighting the permanent nature of the Protocol. Moreover, the law-making power conferred on ministers by section $8 \mathrm{C}$ is extremely broad and the regulations made thereunder are subject to affirmative resolution 55 and unamendable during their scrutiny. In part, the breadth of this power reflects the potential in the Protocol for dynamism in the future relationship between Northern Ireland and the EU.56 However, a

53 Elliott (n 43 above) 387.

54 Allister (n 2 above) [110].

55 EUWA, sched 7, para 8F(1).

56 See eg Katy Hayward, “Flexible and imaginative”: the EU's accommodation of Northern Ireland in the UK-EU Withdrawal Agreement' (2021) 58(2) International Studies 201, 210. 
virtually open-ended power to make law on a permanent basis is hardly an example of specificity, when such law-making is authorised in respect of a relationship which is itself (in some respects) nonspecific. What I mean by this is the scope of what section $8 \mathrm{C}$ allows in law-making. Section $8 C(7)(b)$, for instance, states '[any reference in section $8 \mathrm{C}$ to the Protocol includes a reference to] any provision of EU law which is applied by, or referred to in, the Protocol (to the extent of the application or reference)'. Provisions of EU law referred to in the Protocol are not exhaustively enumerated. Article 13(3), for example, provides for any references in the Protocol to EU Acts as being those Acts 'as amended or replaced', while article 13(4) envisions adoption of acts which fall within the scope of the Protocol without replacing or amending any EU act listed in the Protocol itself. 57 Given the nonspecific nature of the Protocol's objectives ('arrangements necessary to address the unique circumstances on the island of Ireland'), 58 what falls within the scope of the Protocol is, at least arguably, a fairly open-ended question. Admittedly, the implementation of the Protocol's dynamism into domestic law may necessitate some parliamentary legislation, but section 8C provides a constitutional (and incidentally convenient) pathway to avoid the scrutiny involved with parliamentary legislation. Most problematic of all perhaps (from the perspective of specificity) is that section $8 \mathrm{C}(2)$ authorises regulations to modify Acts of the UK Parliament, including the EUWA itself, perhaps foreshadowing some future regulation (still unamendable by Parliament) which avoids all parliamentary scrutiny when incorporating newer and newer EU law as part of the implementation of the Protocol.

Seen in this light, if the operation of one constitutional statute were to impliedly repeal a previous one, then such repeal may have to be construed narrowly in the interests of constitutional certainty and predictability, which are themselves norms of constitutional significance.59 At this point, it is worthwhile to return (briefly) to Laws LJ in Thoburn. In answer to the question of how a court would find that a constitutional statute (or provision) had been repealed, Laws LJ stated: 'I think the test could only be met by express words in the later statute, or words so specific that the inference of an actual determination to effect the result contended for was irresistible.' 60 In the context of the Acts of Union, as Colton $\mathrm{J}$ observed in Allister, the entire constitutional landscape had changed utterly: from the partition of Ireland and the establishment of the Irish Free State in

57 Protocol (n 1 above) C 384 I/99-100.

58 Ibid art 1.3, C $384 \mathrm{I} / 93$.

59 Lord Bingham, 'The rule of law' (2007) 66(1) Cambridge Law Journal 67, 69-70.

60 Thoburn (n 29 above) [63]. 
192261 to the Ireland Act 1949.62 While neither of these legislative developments explicitly repealed any aspect of the Acts of Union, they certainly provided for a specific realignment (and eventual severance) of constitutional relationships and functionality between the UK and Ireland. Thus, insofar as there was any implied repeal of the Acts of Union, such repeal was accompanied by efforts to prevent a constitutional vacuum. The need to prevent such a vacuum may well be a relevant factor when determining whether a constitutional provision has been repealed (and to what extent) by a subsequent constitutional provision. From this perspective, the EUWA (as amended) succeeds in impliedly repealing article VI: not necessarily because of its recentness, but because, by realigning constitutional relationships between Northern Ireland and Great Britain through empowering the implementation of the Protocol (however messy and concerning such empowerment may be), it does not (in itself) create a constitutional vacuum through repeal.

An additional element is the extent to which implied repeal is the only (or only proper) analytical paradigm by which to explain what has happened to article VI. Colton J referred to two reports of the House of Lords' Committee for Privileges (the Committee): The Earl of Antrim's petition 63 and Lord Gray's motion. ${ }^{64}$ Both matters concerned the right of peers to sit in the House of Lords: Antrim concerned the right of 28 Irish peers to sit in the Lords under the Acts of Union, 65 while Gray concerned the right of 16 Scottish peers to sit in the Lords under the Acts of Union 1706-1707.66 In both cases, the Committee found that events of constitutional significance had overtaken the UK, so that neither right applied.67 As with Colton J, the Committee in Antrim did not explicitly hold that the provisions of the respective Acts of Union had been impliedly repealed, only that the claimed right of Irish peers no longer existed, ${ }^{68}$ with the relevant statutory provisions having become 'spent or obsolete or impliedly repealed'. ${ }^{69}$ In Gray, by contrast, the Committee doubted whether the right of Scottish peers was 'fundamental law' at all. 70

61 Irish Free State (Constitution) Act 1922.

62 Allister (n 2 above) [96]. To be clear, this describes constitutional change from the UK perspective, not the Irish perspective.

63 [1967] 1 AC 691 (HL).

64 [2002] 1 AC 124 (HL).

65 Antrim (n 63 above) $709 \mathrm{G}$.

66 Gray (n 64 above) 128F.

67 Respectively, Antrim (n 63 above) 710A, and Gray (n 64 above), 130H.

68 Antrim (n 63 above) 718B, per Lord Reid.

69 Ibid 719E, per Viscount Dilhorne.

70 Gray (n 64 above) 143D, per Lord Hope. 
These two reports, and Antrim in particular, illustrate the myriad perspectives on what happens to a statute which was foundational in an age which no longer exists, and which cannot sensibly be revived. If the Acts of Union were required to be strictly enforced in perpetuity, the effects of such enforcement would be an anachronistic delirium. It might be jarring on a doctrinal level to see the highest judicial officeholders conclude that a provision, enacted by an alwayssovereign Parliament and still very much alive in the statute book, has ceased to have effect, has become obsolete or is now spent (without any indication that it could become obsolete or spent in the legislative text). But at such a sharp intersection between legal doctrine and reality, reality takes precedence. There is an added benefit to leaving open the question whether a constitutional statute has been impliedly repealed or rendered obsolete (or spent) by facts over which the statute itself has no control: the reinforcement of parliamentary sovereignty. As sovereignty encapsulates the ability of the Crown in Parliament to enact legislation, external events rendering its constitutional statutes ineffective do nothing to diminish this ability as a matter of law. Moreover, although not relevant to the judicial task, a finding of obsolescence due to external events preserves a modicum of dignity in a legislative body which might otherwise appear to have enacted a statute in its sleep.

What Antrim and Gray both provide is a basis to conclude that certain constitutional norms no longer apply in a state which would be unrecognisable to those who hoped such norms would be entrenched in perpetuity. Of course, there are problems with this approach, not least the principle that parliamentary sovereignty demands that Acts of the UK Parliament be enforced as such. ${ }^{71}$ Difficult questions would therefore arise: what sort of external events would justify finding that an Act of Parliament has ceased to have effect? How could such a justification sit normatively within a constitution whose bedrock remains the sovereignty of the Crown in Parliament? ${ }^{72}$ More difficult still would be the question of why such a justification should be limited only to constitutional statutes and not ordinary ones. However, as previously discussed, the Supreme Court's observations in HS2 also gave rise to difficulties, as does the doctrine of implied repeal.

Related to this discussion is the Scottish doctrine of 'desuetude', which requires 'a very considerable period, not merely of neglect, but of contrary usage of such a character as practically to infer such completely established habit of the community as to set up a counter

71 See In re UK Withdrawal from the European Union (Legal Continuity) (Scotland) Bill [2018] UKSC 64, [2019] AC 1022 [43].

$72 \quad R$ (Jackson and others) $v$ Attorney General [2005] UKHL 56, [2006] 1 AC 262 [9], per Lord Bingham. 
law or establish a quasi-repeal' of a law. ${ }^{73}$ However, two problems arise with the conclusion that the Acts of Union (or any other constitutional statutes) could be subject to desuetude. First, it appears to be a specifically Scottish doctrine which has no equivalent in the constitutional practice in the rest of the UK (including in respect of Northern Ireland), 74 and anyway appears to apply only to pre-Union Scottish statutes. ${ }^{75}$ Second, even if the doctrine applied, it is not immediately clear that article VI was rendered ineffective through desuetude. This is because, until Brexit and the Protocol, there was no customs border dividing Northern Ireland from Great Britain. This is despite the whole island of Ireland being one epidemiological unit, necessitating sanitary and phytosanitary checks at points of entry into Northern Ireland even before Brexit. ${ }^{76}$ Thus, it is arguable that aspects of the 'same footing' element of article VI applied in the relationship between Northern Ireland and Great Britain, until the incorporation of the Protocol and its commencement in domestic law.

Ultimately, the point of this discussion is not to suggest the correct path: just as there is apparently more than one way to skin a cat, 77 there is more than one perspective on how to resolve conflicts between constitutional statutes. This is relatively uncharted territory for the courts and the strictly legal aspects of the UK constitution. We do not have a wealth of case law on how to deal with constitutional statutes, what is precisely encompassed by the 'constitutional' status and how that sits normatively within existing (and long-standing) constitutional doctrine. In such circumstances, a holistic approach is essential because this issue is far from settled.

What matters in the end from a doctrinal perspective is the 'true meaning' of a legislative enactment, whether or not such meaning aligns with the factual intentions of its enactors. ${ }^{78}$ And where two constitutional statutes conflict, a sensible resolution ought to be preferred over a nonsensical one. In that, Colton $\mathrm{J}$ came to what was possibly the only conclusion: whether or not article VI had in fact been impliedly repealed by the EUWA, its provisions no longer had effect as they did in 1801. The alternative conclusion would have

73 See Brown v Magistrates of Edinburgh (1931) SLT 456, per Lord MacKay (Outer House) 458.

74 Ibid Lord MacKay quoting Lord Eldon in Johnstone $v$ Stott (1802) 4 Paton 274 (HL).

75 A W Bradley, K D Ewing and C J S Knight, Constitutional and Administrative Law 17th edn (Pearson 2018) 61, fn 90.

76 Allister (n 2 above) [60].

77 Having never tried to skin a cat, I do not know how true this is.

78 Black-Clawson International Ltd $v$ Papierwerke Waldhof-Aschaffenburg AG [1975] AC 591, 613G, per Lord Reid. 
irresistibly bled into some other constitutional moments: notably when the UK Parliament gave up legislative supremacy over most of the British empire. The Prime Minister might in that event meet with a spectacularly hostile reception at the next Commonwealth Heads of Government Meeting.

\section{THE DEVOLUTION CHALLENGES}

The Protocol was challenged on the basis not only of the UK constitution, but also that of Northern Ireland. I deal with the second and third grounds of challenge in this section, as both were predicated on largely similar themes arising out of Northern Ireland's constitutional arrangements. Central to these arrangements (and the grounds of challenge covered in this section) are the inter-related concepts of consent and consociationalism. Section 1(1) of the Northern Ireland Act 1998 (NIA) provides that Northern Ireland remains in the UK unless a majority of its people vote to secede from the UK and unite with the Republic of Ireland instead. This wording is reproduced in its entirety from the Belfast (Good Friday) Agreement 1998 (GFA). ${ }^{79}$

The second challenge in Allister proceeded on the basis that the NIA 'protects the status of Northern Ireland under the Acts of Union 1800 and that any diminution in that status can only occur if it has been approved in advance by a referendum held in accordance with the first Schedule of the [NIA]'.80 In other words, the applicants submitted that, in addition to membership within the UK or unification with the Republic of Ireland, the NIA's consent requirement also covers other changes to Northern Ireland's constitutional status, including via the Protocol. In dismissing this argument, Colton $\mathrm{J}$ pointed to $R$ (Miller) $v$ Brexit Secretary, in which a unanimous 11-judge Supreme Court panel had considered the same argument (albeit in the context of the UK's intention to exit the EU) and dispatched it with three sentences. 81 Admittedly, the Supreme Court had to contend with much more than Northern Ireland's constitutional arrangements in Miller, but Northern Ireland's peculiarities have a habit of returning to the judicial arena. Colton $J$, to his credit, explored the issue in greater detail, looking to the GFA as the interpretational backdrop to the NIA. ${ }^{82}$ However, no part of the GFA supported the applicants' argument that Northern Ireland's constitutional arrangements required popular consent for

\footnotetext{
79 The Agreement reached in the Multi-party Negotiations (10 April 1998).

80 Allister (n 2 above) [121].

81 [2017] UKSC 5, [2018] AC 61 [135].

82 Allister (n 2 above) [129]-[135].
} 
changes beyond secession from the UK. ${ }^{83}$ Consequently, this ground of challenge failed.

The third challenge revolved around the Consent Regulations. Per the Protocol, 84 the UK is required to seek the democratic consent of the Northern Ireland Assembly on the question whether articles 5-10 of the Protocol (which relate to the customs and regulatory border) will continue to apply. The consequences of an affirmative vote depend on whether that vote was by a simple majority or a cross-community majority, 85 whereas a negative vote results in the cessation of the application of articles 5-10 and other Protocol provisions on which the foregoing articles depend (only to the extent of such dependence) two years after the negative vote. 86 The relevant point for this challenge was the manner of the Assembly's vote.

Currently, any vote in the Assembly may be made subject to the petition of concern mechanism provided for under section 42(1) of the NIA. Maligned by many but defended by others, the petition of concern is a mechanism which allows a minimum of 30 Members of the Legislative Assembly to bring a motion for a cross-community vote on any matter on which the Assembly is due to vote. If the crosscommunity vote fails, so does the matter underlying it. The petition is an example of the consociationalism built into the GFA and NIA and is a crucial element of ensuring participation in Northern Ireland's politics by its two main communities. However, it has also come under fire for a number of years for being tactically used to defeat bona fide Assembly scrutiny of the Northern Ireland Executive and popular legislative measures. ${ }^{87}$ However, this is not the place for a detailed discussion of its merits.

The Consent Regulations inserted schedule 6A into the NIA, providing for the Assembly's consent vote in connection with the Protocol. Crucially, it also disapplied section 42 (and thus the petition of concern) in respect of the entire voting process. ${ }^{88}$ The challenge in this connection proceeded on the basis of section 42 being a fundamental constitutional provision in Northern Ireland and thus not subject to implied repeal, amendment or disapplication by secondary legislation. 89 The similarities of this challenge to that concerning the

83 Ibid [136].

84 Protocol (n 1 above) art 18(2), C 384 I/102.

85 Ibid art 18.5, C $384 \mathrm{I} / 102$.

86 Ibid art 18.4, C $384 \mathrm{I} / 102$.

87 For detail, see A Deb, 'Judicialising the legislative process: the Petition of Concern' (UKCLA Blog, 14 June 2021).

88 NIA, sched 6A, para 18(5).

89 Allister (n 2 above) [150]. 
Acts of Union were obvious. 90 Moreover, the applicants argued that a part of the EUWA itself prevented the Consent Regulations from having been made: section 10(1)(a) which provides: '[a Minister of the Crown or devolved authority must] act in a way that is compatible with the terms of the Northern Ireland Act 1998'.91

The court's answer to this challenge was to examine the history of the consent vote, which it did in great detail.92 Ultimately, the court's reasoning lay in the breadth of section $8 \mathrm{C}$ of the EUWA, empowering ministers to make any law appropriate to implement the Protocol. Plainly, the Consent Regulations fall within this power, the more so as they faithfully reproduce what the Protocol itself requires in terms of the Assembly's consent. ${ }^{93}$ As an aside, the court did not note in much detail that the applicant's challenge under section 10 of the EUWA was largely upended by the fact that the Consent Regulations also inserted section 56A into the NIA, which provides for schedule 6A to have effect. 94 Thus, it would appear that the Consent Regulations, made under the extremely broad section $8 \mathrm{C}$ power, amended the NIA in a way which would not render the making of the Consent Regulations a breach of section 10. There appears to be nothing unconstitutional (let alone unlawful) about this because, lest we should forget, the Consent Regulations were laid in draft form for affirmative resolution by each of Parliament's Houses (in accordance with the EUWA): the draft was laid on 9 December 2020 and came into force the following day. At such times, legislative scrutiny has taken on a whole new meaning.

Leaving aside the manner of the Assembly's consent vote, the applicants also attacked its substance as being in violation of the consociational heart of Northern Ireland's constitution. This was argued on the basis that the consent vote was a devolved matter because it related to the implementation of an international obligation (arising under the Withdrawal Agreement) which was transferred to the Assembly's competence. 95 Thus, the argument ran, it should be subject to the petition of concern mechanism like any other matter transferred to the Assembly. 96

Colton J turned to the 'paramount' role of the Northern Ireland Secretary in the facilitation of the consent vote (by the making

$90 \quad$ Ibid [149].

91 Ibid [151].

92 Ibid [157]-[164].

93 Ibid [165]-[172].

94 Protocol on Ireland/Northern Ireland (Democratic Consent Process) (EU Exit) Regulations 2020, SI 2020/1500, reg 2.

95 Sched 2, para 3 to the NIA.

96 Allister (n 2 above) [183]. 
of the Consent Regulations and in the process contained within Schedule 6A), 97 concluding:

Plainly, any decision taken by the Assembly to end the application of Articles 5-10 of the Protocol to Northern Ireland would come within the ambit of international relations, including relations with the territories outside the United Kingdom which is not a transferred or devolved matter. 98

Thus, the court held that the consent vote was not a matter transferred to the competence of the Assembly. ${ }^{99}$ However, the court's reasoning on this point deserves a more detailed examination. The consent vote process is plainly a responsibility of the UK Government under the Protocol, which requires the UK Government to 'seek democratic consent in Northern Ireland in a manner consistent with the [GFA]'.100 However, the design of the Protocol equally plainly envisions two actors within this process: the UK Government facilitating the consent vote, and the Assembly reaching a decision on the vote itself. It is the outcome of the Assembly's vote that determines the consequences for articles 5-10 of the Protocol, not any action strictly on the part of the UK Government. It is thus at least arguable that there are two obligations at play - one on the part of the Northern Ireland Secretary and the second on the part of the Assembly. In such circumstances, the court's conclusion that the consent vote in its entirety is an excepted matter under schedule 2 of the NIA appears to lack appropriate nuance.

An analogy may be drawn here with Scotland. In The Scottish Continuity Bill Reference, the Supreme Court considered that:

There is relatively little scope for Scottish legislation to 'relate to' international relations other than by way of implementation of international obligations, unless such legislation were to purport to deal with the power of Ministers of the Crown to exercise its prerogative in foreign affairs, or to create a state of law in Scotland which affected the effectual exercise of that power'. ${ }^{101}$

Although we are concerned here with a power conferred on the Northern Ireland Assembly and not legislation enacted by the Assembly, the analogy is important. As the Supreme Court held in The Scottish Continuity Bill Reference, in the field of international relations, the UK is a single entity. ${ }^{102}$ The relations between the EU and the UK in respect of Northern Ireland are governed by the Protocol, the majority

97 Ibid [184]-[186].

98 Ibid [189].

99 Ibid [190].

100 Protocol (n 1 above) art 18(2), C 384 I/102.

101 The Scottish Continuity Bill Reference (n 71 above) [32].

102 Ibid [29]. 
of which remains in force even if the Assembly votes against the continued application of articles 5-10. Even in such circumstances, the Protocol makes provisions for what happens. ${ }^{103}$ The Assembly's vote changes neither of these facts; far less does it impact the UK Government's ability to exercise the Crown's prerogative powers in foreign affairs or its obligations under the Protocol or the remainder of the Withdrawal Agreement. Thus, it is certainly questionable whether the Assembly's vote would 'come under the ambit of international relations' as Colton $\mathrm{J}$ concluded.104

However, Colton $\mathrm{J}$ provided alternative reasoning to dismiss this ground of challenge, which is much stronger. The judge's alternative reasoning rests principally on the breadth of section $8 \mathrm{C}$ of the EUWA: the Consent Regulations were made pursuant to the power conferred by this section and have to be given effect as authorised by primary legislation. ${ }^{105}$ This was despite the restrictive approach that the courts usually employ when construing secondary legislation which attempts to amend primary legislation. ${ }^{106}$ At this juncture, Colton $\mathrm{J}$ examined generally the relationship between Parliament and the devolved legislatures with reference to Scotland and Northern Ireland,107 concluding:

... the court notes that under section 7 of the Northern Ireland Act the [EUWA] is an 'entrenched enactment' not subject to modification but that regulations made under the Act may be modified by an Act of the Assembly which does not arise in this case. ${ }^{108}$

This appears to suggest that the Assembly may modify the Consent Regulations, but the Court did not go into much detail for its reasons in reaching this conclusion. This is a somewhat problematic conclusion reached by the court, for reasons which are worth detailing. The court's primary reference for this conclusion appears to be section 5(6) of the NIA which states:

This section does not affect the power of the Parliament of the United Kingdom to make laws for Northern Ireland, but an Act of the Assembly may modify any provision made by or under an Act of Parliament in so far as it is part of the law of Northern Ireland. 109

103 Protocol (n 1 above) art 18.4, C 384 I/102.

104 Allister (n 2 above) [189].

105 Ibid [205].

106 Ibid [193]-[199].

107 Ibid [207]-[210].

108 Ibid [211].

109 Allister (n 2 above) [209]. 
However, section 5(6) cannot be read in isolation from the rest of the section or indeed sections $6-8$, to which section 5 is subject.110 Section 5 lays down formal requirements for the Assembly to make Acts, culminating in the explicit recognition of parliamentary sovereignty at section 5(6). Section 6 outlines matters outside the Assembly's competence, which includes excepted matters under schedule 2 insofar as the corresponding Assembly Act (or provision of such an Act) is 'not ancillary to other provisions (whether in the Act or previously enacted) dealing with reserved or transferred matters'.111 'Ancillary' is defined as a provision 'which provides for the enforcement of those other provisions or is otherwise necessary or expedient for making those other provisions effective; or which is otherwise incidental to, or consequential on, those provisions' ${ }^{112}$ If the court's conclusion that the entire consent vote process is an excepted matter is followed to the letter, the Assembly is, by operation of section 6, prohibited from making any legislative modifications to that process.

There is, however, a related point in terms of the Assembly's competence to modify the Consent Regulations. Schedule 2 of the NIA lists a number of excepted matters upon which the Assembly cannot tread, including parts of the NIA itself. The new section 56A of the NIA (which gives effect to the schedule 6A consent vote process) is not on this list. Thus, as a matter of strict statutory construction, there is a considerable grey area. The Northern Ireland Secretary made the Consent Regulations pursuant to section $8 \mathrm{C}$ of the EUWA, in order to give domestic effect faithfully to the requirements of article 18 of the Protocol. However, although the EUWA is protected from modification by the Assembly, ${ }^{113}$ the part of the NIA giving effect to the consent vote process is not. If this part or schedule $6 \mathrm{~A}$ is subsequently modified by the Assembly, such modifications may breach the UK Government's obligations under the Protocol if those modifications deviate from the text of the Protocol itself (for example, by requiring cross-community consent under section 42 of the NIA). Of course, the Consent Regulations could have modified schedule 2 of the NIA by entrenching section 56A and schedule 6A, but they did not. Moreover, while Parliament could not have amended the Consent Regulations while considering them, it could have refused to approve them and asked the Northern Ireland Secretary to provide a modified draft which closed this potential loophole. But neither of these steps was taken. Legislative scrutiny, indeed.

110 NIA s $5(1)$

111 Ibid s 6(2)(b).

112 Ibid s 6(3).

113 Ibid 7(1)(e). 


\section{THE ECHR AND EU LAW CHALLENGES}

The fourth and fifth grounds of challenge were premised, respectively, on article 3 of Protocol 1 (A3P1) to the European Convention on Human Rights (ECHR) 114 and articles 50 and 10 of the Treaty on European Union (TEU). 115

The central argument of the A3P1 challenge was what could be described as a variation on the famous slogan from Revolutionary America: 'no taxation without representation',116 turning to 'no implementation without representation' in the case of the Protocol. Essentially, the argument ran that, since Northern Ireland could no longer elect representatives to the European Parliament, it had no democratic say in the implementation of EU law which is required by the Protocol.117 The court examined the provisions of the Protocol in detail, with a particular focus on its dynamism, 118 concluding that the right to free expression 'of the opinion of the people in the choice of the legislature' as guaranteed by A3P1 was engaged, but only in respect of future EU law being made, 119 rather than the EU law already incorporated via the Withdrawal Agreement and Protocol, which was made by Parliament. 120

For Colton J, the applicants' challenge fell because of two reasons: first, the implementation of future EU law would have to go via the Joint Committee constituted under the Protocol, in which the UK Government plays a full part. ${ }^{121}$ Secondly, Northern Ireland residents could elect representatives to the Assembly, which has a role in relation to the consent vote, and Parliament, which 'can amend or repeal [the statutes relating to the Withdrawal Agreement]'.122 The Court also pointed to article 16 of the Protocol which allows either the UK or the EU to take unilateral 'safeguard measures' to remedy 'serious economic, societal or environmental difficulties that are liable to persist' as a result of the application of the Protocol, as the 'ultimate protection'.123 No comments were made about the likelihood that Parliament would amend or repeal the Withdrawal Agreement statutes

114 Convention for the Protection of Human Rights and Fundamental Freedoms (European Convention on Human Rights, as amended) (ECHR) art 3, Protocol 1.

115 Treaty on European Union (Lisbon Treaty) art 50.

116 Sarah Kay, 'Is the Northern Ireland Protocol unlawful? Analysis of the High Court judgment' (EU Law Analysis, 3 July 2021).

117 Allister (n 2 above) [215]-[216].

118 Ibid [220]-[238].

119 Ibid [241].

120 Ibid [240].

121 Ibid [260].

122 Ibid [259].

123 Ibid [263]. 
(or the corresponding damage to the rule of law for legislating in breach of an international agreement). ${ }^{124}$

A related (though scantly argued) point with the A3P1 challenge was that the Protocol would be a breach of article 14 of the ECHR, which prohibits discrimination in the enjoyment of the rights under the ECHR, on grounds both explicitly enumerated and unenumerated ('other status'). Colton J considered that Northern Ireland residence could conceivably fall within 'other status', so that article 14 was engaged in the context of the A3P1 right to vote. ${ }^{125}$ However, the court was unable to find an analogous comparator by which to determine whether there had been prohibited discrimination: if comparison was to be made with residents of Great Britain, then they are not subject to the Protocol anyway and thus their voting rights would not be in issue. 126

Ultimately, the court determined that article 14 was not engaged,127 but that, even if it was, the Protocol was justifiable under either proportionality or the 'manifestly without reasonable foundation' test due to the fundamental reasons for the Protocol's necessity (relating to the unique conditions on the island of Ireland as a result of Brexit). ${ }^{128}$ The court thus found the Protocol to be distinctly within the UK's margin of appreciation ('matters of political judgment'), 129 thereby escaping a particularly searching judicial enquiry. Murray makes the important point that, had the court concluded otherwise, 'this would have dramatic consequences for countries like Norway and Switzerland which have long been "rule takers" in their relationship with the EU'.130

The EU law challenge was premised on the ability of the EU to agree the Withdrawal Agreement. The applicants contended that article 50 TEU did not envision a formal future-facing document like the Protocol (especially one which subjects a part of the departing state to EU law permanently) ${ }^{131}$ and that the EU could not agree such a document

124 For example, when the now UK Internal Market Act 2020 was first introduced and the Northern Ireland Secretary stated in the House of Commons that the then Bill as drafted would breach international law in a 'specific and limited' way (HC Deb 8 September 2020, vol 679, col 509) and the criticism which followed, including from the Lord Chief Justice of Northern Ireland, Sir Declan Morgan: see Freya McClements and Colin Gleeson, 'UK Brexit plan could undermine rule of law domestically, says NI chief justice' The Irish Times (Dublin, 9 September 2020).

125 Allister (n 2 above) [273], based heavily on the Supreme Court's judgment in $R$ (Stott) v Justice Secretary [2018] UKSC 59, [2020] AC 51, see Allister [271][272].

126 Ibid [274].

127 Ibid [274].

128 Ibid [276].

129 Ibid [277].

130 Murray (n 32 above).

131 Allister (n 2 above) [290]. 
in any event because the democratic deficit contained therein was in breach of article $10 \mathrm{TEU}$ (rehashing some of the A3P1 arguments). ${ }^{132}$ In answer to the first point, Colton $\mathrm{J}$ found nothing in the text of article 50 which precludes agreement of the Protocol (or indeed a document of its kind) ${ }^{133}$ and the judge adopted his analysis under the A3P1 challenge in answer to the second point, citing the impropriety of interfering with the sovereign will of Parliament as expressed in primary legislation. ${ }^{134}$

Although the recentness of the invocation of Article 50 meant that the court did not have precedent on which to rely or by which to be informed, Colton $J$ should be commended for resolutely avoiding the kind of adventure embarked upon by the Bundesverfassungsgericht in May 2020, in which the German Constitutional Court found that the Court of Justice of the European Union had 'manifestly exceed[ed] [its] judicial mandate' under EU law when determining the proportionality of the Public Sector Purchase Programme of the European Central Bank. ${ }^{135}$

\section{CONCLUSION}

Given that the applicants in Allister have already indicated their intention to appeal Colton J's judgment, 136 there is not yet a conclusion to these proceedings. However, two important points need to be borne in mind. First, just as Colton $\mathrm{J}$ repeatedly indicated that he was bound by previous judgments of the Supreme Court, so too is the Northern Ireland Court of Appeal. If the issues encapsulated by Allister require examination from a first-principles perspective (I think some, not all, issues do), the chances of such an examination are highest in the Supreme Court. This is not, however, to suggest that the Court of Appeal should be leapfrogged; there is no doubt that the Supreme Court (if the appeal goes that far) would benefit from the observations and conclusions of Northern Ireland's highest court. Rather, my point is about recognising the reality of stare decisis: only the Supreme Court is unbound by decisions made by domestic UK courts and thus has the most freedom to consider the issues in Allister from the basis of first principles, including whether to maintain the 'constitutional statutes' designation at all. Second, the issues raised in Allister are neither academic nor esoteric. Regardless of whether one approves or

132 Ibid [292].

133 Ibid [291].

134 Ibid [297].

135 Judgment of the Second Senate (5 May 2020) 2 BvR 859/15 [154].

136 'Politicians react to High Court ruling NI Protocol is lawful' (BBC News, 30 June 2021). 
disapproves of Brexit and the Protocol, the case raises questions with far-reaching consequences for constitutional principle and practice in the UK. Statutory interpretation can be a difficult exercise, but constitutional statutes make it even more so. How such statutes are given effect and which are preferred in the event of a conflict between them have consequences beyond the immediate case in which such questions are answered. Colton $\mathrm{J}$ made an admirable effort at answering these questions, but his word may not be the last. 